\title{
Review
}

\section{American mourning: Tragedy, democracy, resilience}

\author{
Simon Stow \\ Cambridge University Press, Cambridge, 2017, \\ ISBN: 978-1-316-61058-9
}

Contemporary Political Theory (2019) 18, S98-S101. https://doi.org/10.1057/s41296017-0183-2; published online 21 December 2017

'The dead are alive in the American polity.' With this line Simon Stow begins his wonderful book, American Mourning: Tragedy, Democracy, and Resilience, which unfolds as a thorough and thoughtful examination of the multiform politics of mourning. As Stow defines it, public mourning is the 'attempt to employ grief for political ends' (p. 5). Regardless of the specific subject of public mourning, Stow argues that it is the means through which the dead are enlisted politically that powerfully shape lived understandings of political identity and community. The pressing question for Stow is whether the discourses and rituals of public mourning will serve the realization of democratic values, such as 'productive discussion, good judgment, and careful deliberation' (p. 5) - or whether public grief will serve as a pretext to insulate arguments from critical scrutiny or collapse political struggles into morality tales about good and evil. While the former style of public mourning is 'democratically productive,' the latter marks an 'unproductive mobilization of grief' that can lead to abject disaster (p. 5).

In this light, Stow argues that the American polity in recent years has displayed a worrisome amount of unproductive and undemocratic grief - especially in the time after 'the planes' (p. 1). Stow argues that the felt grief at the loss of life in the terrorist attacks of 11 September 2001 was mobilized and manipulated in ways that stigmatized dissent, skewed public debate, and ultimately justified a catastrophic series of military interventions whose full, tragic consequences are still unfolding. How might democracies mourn better? American Mourning attempts to think through this question, and at the heart of its response is what Stow calls an 'outlandish proposal,' namely that the American polity should find ways to 'mourn the death of Osama bin Laden' (p. 18).

While striking and perhaps even absurd on its face, Stow finds a precedent of sorts for his outlandish proposal in the experience of Greek tragedy. Specifically, he refers to the staging of Aeschylus's The Persians, which imagined the consequences of the Battle of Salamis (in which the outnumbered Athenian fleet

(c) 2017 Macmillan Publishers Ltd., part of Springer Nature. 1470-8914 Contemporary Political Theory Vol. 18, S2, S98-S101 www.palgrave.com/journals 
defeated the invading Persian army) from the perspective of the vanquished Persians. For Stow, the play shows that it is possible to "consider [the] enemy in all of its complexity rather than simply as a hypertrophied evil' (p. 21). Despite Aeschylus having himself fought against - and lost family members to - the Persian army, he was arguably able (scholars are divided on this question) to sympathetically portray the grief of his enemies. Stow imagines this as a kind of 'agonistic humanism' that does not flatten differences between individuals or groups but provides a platform for examining and interrogating those differences in democratically productive ways.

Stow's turn to Greek tragedy, philosophy (Plato), and history (Thucydides) reflects his methodology of 'classicization,' a term coined by the political theorist Bonnie Honig to describe an approach to ancient materials that consciously eschews universalistic claims in favor of provocative 'analogies that might illuminate our condition' (Honig, 2013, p. 32). Following other scholars in this vein, such as Peter Euben, Stow finds within the ancient Greek experience a means of productive disorientation for our own democratic understandings and practices. The ancient Athenians, for instance, were highly sensitive to the dangers of public grief - not only the ways in which it reflected the vice of hubris but also its tendency to morph into mênis, a form of 'grief-wrath' that the historian Nicole Loraux has called the 'worst enemy of [democratic] politics.' Stow suggests that the Great Dionysia - the annual spring festival at which the tragedies were performed - represented a collective ritualistic response to the dangers of public grief, through which its tendency to morph into an enraged desire for vengeance was tempered by the critical portrayal of Athenian values and, in the case of The Persians, the sympathetic portrayal of the city's enemies. Greek tragedy, for Stow, reflected what the political theorist William Connolly has called a 'bicameral orientation' (p. 36) to political life that is more suitable for successfully navigating the politics of grief.

Beyond the Greek experience, Stow discusses examples of democratically productive mourning in American history, ranging from Abraham Lincoln's Gettysburg Address to the public oratory of Frederick Douglass and the broader African American funeral traditions forged in the face of the violence of slavery and segregation. Stow also examines in fine detail the politics of veteran homecoming and the cross-disciplinary literature on 'resilience.' Stow's treatment of the former is especially powerful, as he shows how discourses of heroism and sacrifice are often deployed in ways that conceal both the complexities of war and citizens' collective responsibility for returning veterans and for the wars from which they are returning. He examines in detail the case of Pat Tillman, the former National Football League player and Army Ranger, who was killed while on deployment in Afghanistan. While initially Tillman's death was attributed to enemy fire, weeks after his funeral it was disclosed that he was killed in a friendly fire incident. Stow shows how both Tillman's criticisms about the conflict and his

(C) 2017 Macmillan Publishers Ltd., part of Springer Nature. 1470-8914 Contemporary Political Theory Vol. 18, S2, S98-S101 S99 
professed atheism - not to mention the suspicious circumstances surrounding his death - were swept away by nationalistic funeral discourses emphasizing god, country, and military honor.

Within the subfield of political theory, Stow's book makes a number of contributions to debates over agonism, the politics of recognition vs. acknowledgment, and the place of humanism within democratic discourse and praxis. Because Stow filters these theoretical discussions through the lens of public mourning, the book will also be of interest to scholars of collective memory, historical injustice, and social trauma. Yet despite the book's obvious strengths, there are a few missed opportunities for depth or clarification. In particular, Stow chooses to focus on political discourses and decisions surrounding grief - not psychological motivations or dynamics. He does so in favor of the 'potentially more illuminating' (p. 4) account of public mourning provided by the ancient Greeks. Yet the Greeks were keen psychologists - perhaps even psychoanalysts - avant la lettre. Plato's criticism of funeral discourse in the dialogue Menexenus, for instance, implies an account of human psychology focused on our susceptibility to exaggerated accounts of greatness in the face of grief or loss. Stow's bracketing of psychoanalysis is a missed opportunity to explore the power of defenses such as idealization and demonization that haunt discourses and rituals of public mourning - not to mention the conditions under which a more constructive and critical approach might be motivational for participants.

Another tension in the text is between Stow's prescribed 'tragic ethos' - with its emphasis on complexity and ambiguity - and his repeatedly deployed binary between democratically productive and unproductive forms of grief. For Stow, the former are tragic, agonistic, and humanistic, whereas the latter are nostalgic, nationalistic, and romantic. These distinctions have some purchase, but Stow acknowledges at one point an ambivalence within nostalgia between its 'restorative' and 'reflective' instantiations (p. 151). This reviewer wonders if a similar ambivalence could be traced within nationalistic or romantic discourses; in fact undertaking this work would seem consistent with Stow's tragic humanism. What would it mean to take seriously - at least provisionally - nationalist or nostalgic discourses of grief that, while potentially problematic, emerge from and are sustained by complex individuals and fellow citizens? Perhaps those citizens resemble what James Baldwin named as the representatives of 'a very complex country which insists on being simple minded' (Baldwin, 1986), but perhaps the complexities of the country and its citizens could be unpacked and explored through novel forms of civic engagement and collaboration. Such labors would reflect a spirit of democratic commitment while simultaneously clarifying differences within and across the polity - which again seems consistent with Stow's democratic agonistic humanism.

Unfortunately, Stow does not see many opportunities for citizens to engage in such work. Unlike the ancient Athenians, Americans have few occasions for 
ritualized togetherness - especially ones that could foster a critical or democratically constructive ethos. For this reason, Stow envisions a 'text-based tragic mourning,' in which the democratic pedagogy of a tragic ethos is cultivated within 'reader-citizens' (p. 194). There is much to recommend this strategy in, as Stow puts it, 'an age fractured by political, socioeconomic, and cultural divisions' (p. 199). However, a strictly text-based approach to public mourning in an increasingly polarized age will, it seems likely, be insufficient to develop broader public awareness of these fractures or divisions, let alone cultivate the public will to address them in democratically productive ways. Perhaps that is the tragic fate confronting American democracy at this moment.

On the whole, American Mourning is a book of brilliant insights and thoughtful interpretations. Any scholar or student interested in the politics of mourning will find it to a major contribution to their understanding of these ongoing and urgent issues.

\section{References}

Baldwin, J. (1986). Speech at the National Press Club. Washington D.C. 10 December. Honig, B. (2013). Antigone Interrupted. Cambridge: Cambridge University Press.

David W. McIvor

Colorado State University, Fort Collins, CO 80523, USA david.mcIvor@colostate.edu 